\title{
Suradnja roditelja i škole u Hrvatskoj: sličnosti i razlike urbanih $i$ ruralnih sredina ${ }^{1}$
}

\author{
Renata Miljević-Riđički \\ Učiteljski fakultet Sveučilišta u Zagrebu
}

\section{Tea Pahić \\ Učiteljski fakultet Sveučilišta u Zagrebu, Odsjek Čakovec}

\author{
Vlasta Vizek Vidović \\ Institut za društvena istraživanja u Zagrebu, \\ Centar za istraživanje i razvoj obrazovanja \\ renata.miljevic@ufzg.hr
}

\begin{abstract}
SAŽETAK Cilj istraživanja bio je provjeriti razlikuju li se roditeljske procjene suradnje i zadovoljstva vlastitom uključenosti u život škole iz urbano/ruralne perspektive. Rad je dio većeg, međunarodnog istraživanja koji se bavi participacijom roditelja u životu škole. Uzorak se sastoji od 1052 roditelja djece od drugog do osmog razreda iz 30 osnovnih škola u Hrvatskoj. 16 škola nalazi se u urbanim, a 14 škola u ruralnim područjima. 562 ili 53,4\% roditelja je iz urbanih sredina, a 490 ili 46,6\% roditelja je iz ruralnih sredina.
\end{abstract}

Rezultati pokazuju da roditelji općenito nastavu i izvannastavne aktivnosti procjenjuju isključivo zaduženjem škole, što ukazuje na tradicionalan pristup suradnji roditelja i škole. Međutim, odgoj djeteta i njegovo zadovoljstvo školom vide kao zajedničku odgovornost škole i roditelja, što ukazuje na mogućnost razvoja partnerskog odnosa škole i roditelja. Roditelji uglavnom vide vlastiti nedostatak vremena kao najznačajniju prepreku suradnji škole i roditelja, međutim, taj nedostatak značajno više naglašavaju roditelji urbanih sredina. Roditelji ruralnih područja općenito su zadovoljniji različitim načinima sudjelovanja u životu škole.

\footnotetext{
$1 \mathrm{Rad}$ je temeljen na rezultatima istraživanja provedenog u okviru međunarodnog projekta NACIONALNO ISTRAŽIVANJE O RODITELJIMA U ZEMLJAMA JUGOISTOČNE EUROPE - ROditeljske potrebe, očekivanja i iskustva vezana uz uključenost u život škole (National Survey of Parents in South East European Countries) 2009-2010. Istraživanje je omogućeno zahvaljujući sredstvima Programa za podršku u obrazovanju Instituta Otvoreno društvo.
} 
Urbano/ruralne razlike roditeljskih procjena u većini potvrđuju polaznu pretpostavku o većoj povezanosti roditelja i škole u ruralnim područjima, kao i općenito veće zadovoljstvo komunikacijom i utjecajem na školu kod roditelja ruralnih područja.

Ključne riječi: suradnja roditelja i škole, urbana i ruralna područja, tradicionalni pristup, partnerski pristup.

\section{UVOD}

Važnost roditeljskog surađivanja sa školom je neupitna, a prema školskim propisima obavezna, te postoji veliki broj istraživanja koja dokumentiraju povezanost dječjeg školskog postignuća i roditeljske uključenosti (Daniel, 2011.; Jeynes, 2005.; Kainz i Aikens, 2007.). Ipak, nekim aspektima suradnje škole i roditelja u istraživanjima se ne pridaje dovoljna pažnja. Jedan od tih aspekata je sredina u kojoj se škola nalazi. Tako, na primjer, neki autori navode kako na stupanj roditeljskog sudjelovanja i zadovoljstva školom može utjecati pripadnost gradskoj, odnosno seoskoj sredini (Shouse, 1997., prema Feuerstein, 2000.; McBride, Bae i Wright, 2002.). Manje, bolje povezane seoske sredine svojom strukturom općenito povećavaju uključenost roditelja u živote svoje djece, pa tako i u njihov odgoj i obrazovanje, i po tome su u prednosti pred školama u velikim gradovima. (Bauch, 2001.).

Istraživači navode prednosti seoskih škola u mogućnostima suradnje s roditeljima iz sljedećih razloga: škola i zajednica su više povezane nego u gradskim sredinama, stanovnici ruralnih zajednica općenito osjećaju veću pripadnost i uključenost u zajednicu, roditeljsko sudjelovanje je veće nego u gradu u svim aspektima dječjeg života, škola i crkva tješnje surađuju, lokalna poduzeća su sklonija pomagati školi, a članovi ruralne zajednice daju svoj doprinos u kurikularnim aktivnostima škole (Hornby i Witte, 2010.a).

U ruralnim sredinama bolja je i međusobna komunikacija među obiteljima, te se obitelji uzajamno mogu poticati na suradnju sa školom ili informirati o tome (McBride i sur., 2002.). Seoske škole često su kulturalno i društveno središte mjesta. Odnosi s ljudima važniji su u seoskim nego u gradskim sredinama, te škole imaju pozitivniju klimu (Bauch, 2001.). Mogući su i češći neformalni susreti roditelja i učitelja te roditelji mogu biti veća pomoć u školovanju svoje djece nego što je to u gradskim sredinama (Hornby i Witte, 2010.a). "Ruralni kontekst ima svoj vlastiti set osobina koji čini seoske škole dramatično drugačijim od njihovih metropolitanskih partnera" (Bauch, 2001.: 204.).

Sličan dojam stekli smo u razgovorima s fokus-grupama roditelja u Hrvatskoj provedenim u okviru spomenutog međunarodnog istraživanja. Roditelji jedne gradske škole su na pitanje: Što je po vašem mišljenju glavna prepreka većoj uključenosti roditelja u život škole odgovarali: 
Užasno smo svi zauzeti, toliko puno posla, svega... Kad nas se želi uključiti onda u principu mi nemamo vremena i to vam je problem. ${ }^{2}$

Nasuprot tome u fokus-grupi jedne seoske škole čuli smo da je škola dosta otvorena za roditelje, da uoči Božića i Uskrsa imaju zajedničke radionice s djecom, te da na roditeljskim sastancima roditelji imaju priliku u malim grupama raspraviti određene situacije i dati svoje mišljenje. Također smo čuli izjavu: Ja sam zadovoljan. Imamo brojeve mobitela učiteljica i ravnateljice. ${ }^{3}$

Ovi navodi u skladu su s nalazim drugih autora koji drže kako bolje međusobno poznavanje roditelja i učitelja u manjim mjestima dovodi i do bolje suradnje sa školom nego što je to slučaj s urbanim sredinama. Jeynes (2005.) u svojoj metaanalizi 41 istraživanja ističe kako je zbog specifičnosti života u urbanim sredinama, koje obilježava rastući broj razvoda, veliki broj obitelji u kojima rade oba roditelja i u kojima je, prema društvenim istraživanjima, prisutan specifičan socijalni pritisak na djecu razmjerno malo istraživanja posvećeno roditeljskoj uključenosti u školski život premda su obrazovne potrebe i rizici znatno veći. Analizirajući odnos roditeljske uključenosti i uspjeha učenika gradskih osnovnih škola Jeynes dolazi do zaključka da je roditeljska uključenost u urbanim sredinama toliko važna za školsku uspješnost, da čak nadilazi učinke socio-ekonomkog statusa, rasne pripadnosti, spola itd. Redovita je pojava da roditelji učenika sa slabim školskim uspjehom ne surađuju sa školom. Uz to se pokazalo se da su programi uključivanja roditelja u život škole u američkim urbanim sredinama bili vrlo učinkoviti za roditelje nižeg socio-ekonomkog statusa (Jeynes, 2005.). Naša je pretpostavka da bi se uključenost roditelja u život škole u seoskim sredinama mogla razlikovati od participacije roditelja u gradskim sredinama radi nekih specifičnosti seoske sredine.

Na temelju rezultata prethodnih istraživanja u ovom istraživanju cilj nam je provjeriti kako roditelji procjenjuju svoje zadovoljstvo suradnjom sa školom iz urbano/ ruralne perspektive. Istraživanje je dio šireg međunarodnog projekta (provedeno u 10 zemalja Jugoistočne Evrope), kojim se žele ispitati roditeljske potrebe, očekivanja i iskustva u odnosu na nastojanja škole da roditelje uključe u život škole. Svrha istraživanja odnosila se na unapređenje kvalitete osnovnoškolskog obrazovanja ističući važnost partnerskog odnosa škole i roditelja. Istraživanje je provedeno uz suglasnost Ministarstva znanosti, obrazovanja i športa Republike Hrvatske.

Istraživanje roditeljske participacije temelji se na teoriji roditeljske uključenosti Joyce Epstein (Epstein i sur., 2009.), čije su najvažnije postavke: roditelji i škola dijele odgovornost za socijalizaciju djeteta; ciljevi i zadaci roditelja, škole i zajednice se preklapaju; za dječji rast i razvoj najvažniji konteksti su obitelj, vrtić, škola i zajednica.

2 Naziv stranice (http://www.see-educoop.net/aeiq/outputs.htm)

3 Razgovore s fokus-grupama vodila jedna od autorica ovog članka u 6. mjesecu 2009. god. 
U skladu s navedenim ciljem problemi ovog rada određeni su na sljedeći način:

1. Utvrditi jesu li roditelji u Hrvatskoj usmjereni na tradicionalni ili partnerski odnos sa školom te ispitati postoje li razlike u orijentaciji prema suradnji sa školom između roditelja urbanih i ruralnih sredina.

2. Usporediti procjene roditelja urbanih i ruralnih sredina u pogledu otvorenosti škole, čimbenika koji su potencijalna prepreka suradnji sa školom, zadovoljstva ostvarenom komunikacijom i zadovoljstva cjelokupnom mogućnošću utjecaja na obrazovanje.

\section{METODA}

\section{Uzorak}

Uzorak ispitanika u provedenom istraživanju čini 1052 roditelja djece od drugog do osmog razreda iz 30 osnovnih škola u Hrvatskoj, pri čemu je 16 škola iz urbanih i 14 škola iz ruralnih područja (Prilog 1). Prosječan broj učenika u školama urbanih sredina iznosi $\mathrm{M}=632,28 \mathrm{uz} \mathrm{sd}=255,866$, a u školama ruralnih sredina $\mathrm{M}=$ 294,64 uz sd $=130,458$. Od ukupnog broja roditelja njih 562 ili 53,4\% čine roditelji iz urbanih i 490 ili 46,6\% roditelji iz ruralnih sredina.

Uzorak je odabran metodom dvodimenzionalnog stratificiranog slučajnog odabira, a stratifikacija je provedena prema relevantnim geografskim područjima $s$ obzirom na urbano/ruralno razlikovanje. Prikupljanje podataka provedeno je u drugoj polovici 2009. godine od strane agencije PULS, uz odobrenje Ministarstva znanosti obrazovanja i športa. PULS se u svojim ispitivanjima koristi znanstvenim metodama i obvezuje se na etičnost u radu. Roditelji su intervjuirani u svojim domovima.

\section{Instrument}

U istraživanju su korišteni opsežni anketni upitnici kojima se ispituje roditeljska participacija u školovanju djeteta. Upitnici su konstruirani prema teorijskom modelu Joyce Epstein koji uključuje šest područja: roditeljstvo, komunikacija škole i roditelja, podrška djeci u učenju kod kuće, volontiranje roditelja u školi, sudjelovanje u donošenju odluka i upravljanju školom i suradnja između škole i zajednice (Dauber i Epstein, 1989.), te percepcija roditeljske uloge i uloge škole u odgoju i obrazovanju djeteta prema modelu tradicionalnog nasuprot partnerskog odnosa roditelja i škole Sheridan i Krachowill (2007.). Glavnom ispitivanju prethodili su razgovori u fokus grupama koji su poslužili kao osnova za konstrukciju primijenjenih upitnika.

Upitnici korišteni u istraživanju i izvještaj iz fokus-grupa dostupni su na stranici http://www.see-educoop.net/aeiq/outputs.htm. 
Za potrebe ovog rada izdvojili smo one varijable koje se odnose na gore navedene probleme istraživanja.

Kako bi se utvrdilo jesu li usmjereni na tradicionalni ili partnerski odnos sa školom roditelji su na deset čestica upitnika "Tradicionalni nasuprot partnerskog odnosa" procjenjivali u kolikoj je mjeri svaka od navedenih stvari posao škole a koliko obitelji (roditelja). Svoje su procjene zaokruživali na skali Likertovog tipa od 1 do 5 , pri čemu 1 = u potpunosti je posao škole, $2=$ više je posao škole nego roditelja, $3=$ posao i škole i roditelja, $4=$ više posao roditelja nego škole i $5=$ u potpunosti je posao roditelja.

Otvorenost škole procjenjivala se kroz šest čestica, koje se odnose na pristupačnost nastavnika, ostalih roditelja i ravnatelja škole, na skali Likertovog tipa od 1 do 4, pri čemu 1 = ne slažem se, 2 = donekle se slažem, 3 = prilično se slažem, $4=u$ potpunosti se slažem, a roditeljima je bila ponuđena i mogućnost da se izjasne sa "ne mogu procijeniti". Tri se čestice odnos na pristupačnost (otvorenost) nastavnika/ razrednika, dok se druge tri čestice odnose na pristupačnost (otvorenost) ostalih roditelja i ravnatelja škole.

Drugi čimbenici koji djeluju kao prepreka suradnji škole i roditelja procjenjivani su na osam tvrdnji, također na skali Likertovog tipa od 1 do 4 , pri čemu 1 = uopće se ne slažem, 2 = uglavnom se ne slažem, 3 = uglavnom se slažem i 4 = slažem se u velikoj mjeri. Faktorskom analizom čestica, po metodi glavnih komponenata uz Varimax rotaciju, ekstrahirala su se dva faktora $(\mathrm{KMO}=$ 0,823) koji objašnjavaju ukupno 60,35\% varijance rezultata. Prvi faktor, nazvan faktorom školskih prepreka suradnji sastoji se od 5 čestica: "Nastavnici/učitelji ne znaju kako komunicirati s roditeljima", "Nastavnici/učitelji nisu zainteresirani za komunikaciju s roditeljima", "Nastavnici/učitelji imaju previše posla kako bi komunicirali s roditeljima", "Škola nema kapaciteta za komunikaciju sa svim roditeljima" i "Škola i roditelji obično su u sukobu". U drugi faktor ulaze 3 čestice koje predstavljaju faktor roditeljskih prepreka suradnji: "Roditelji nisu zainteresirani za sudjelovanje u školskim aktivnostima", "Roditelji nemaju vremena informirati se o školskim aktivnostima" i "Roditelji ne znaju kako komunicirati s nastavnicima/učiteljima".

Zadovoljstvo ostvarenom komunikacijom sa školom roditelji procjenjuju kroz čestice: "Ja/mi smo jako zadovoljni kvalitetom i kvantitetom informacija koje dobivamo od škole" i "Ja/mi smo zadovoljni različitim načinima na koje se možemo uključiti u rad škole". Zadovoljstvo s mogućnošću utjecaja na obrazovanje svog djeteta procjenjuje se kroz čestice: "Ja sam/mi smo zadovoljni načinima na koje možemo utjecati na obrazovanje svog djeteta" i "Ja sam/mi smo zadovoljni načinima na koje možemo utjecati na školu općenito". Čestice se procjenjuju na skali Likertovog tipa od 1 do 4 , pri čemu 1 = uopće se ne slažem, 2 = donekle se slažem, 3 = prilično se slažem i $4=u$ potpunosti se slažem. 


\section{REZULTATI}

Zbog asimetričnosti distribucije dobivenih rezultata u statističkoj obradi koristili smo se uglavnom testovima neparametrijske statistike, a kod interpretacije rezultata koristili smo medijan kao najprimjereniju mjeru centralne tendencije. U tabelama se radi usporedbe daju prikazi različitih mjera centralne tendencije. Za testiranje statističke značajnosti razlika u procjenama roditelja urbanih i ruralnih područja upotrijebljen je Mann-Whitney U test.

\section{Tradicionalni nasuprot partnerskog odnosa}

Iz dobivenih rezultata vidljivo je da roditelji u Hrvatskoj u nekim segmentima gotovo u potpunosti prihvaćaju partnerski odnos roditelja i škole, međutim neke segmente školskog života vide isključivo, ili uglavnom, kao posao roditelja ili posao škole. Tako roditelji smatraju da je isključivo posao škole da učini sve kako bi nastava bila dobra i kako bi njihovo dijete bilo sigurno u školi $(\mathrm{Mdn}=1)$, kao i da je većim dijelom odgovorna za organizaciju dobrog izvannastavnog programa $(M d n=2)$. Isključivim poslom roditelja vide dužnost da se pobrinu da dijete napiše domaću zadaću ( $\mathrm{Mdn}=5)$, dok za sva ostala pitanja smatraju da su uglavnom podjednako odgovornost i škole i roditelja $(\mathrm{Mdn}=3)$ (Tablica 1).

Iako roditelji urbanih i ruralnih sredina daju prilično ujednačene procjene (varijabilitet procjena je nizak) Mann-Whitney U test ukazuje da se mišljenje roditelja urbanih i ruralnih sredina razlikuje za većinu pitanja iz ovog upitnika (Tablica 1). Tako roditelji iz ruralnih područja u nešto većoj mjeri nego roditelji urbanih područja smatraju da je i njihov doprinos u realizaciji nastave važan $(p<0,05)$ iako većina roditelja $i$ jedne i druge populacije smatra da bi to pitanje trebalo biti isključivo briga škole. S druge strane, iako obje populacije roditelja vide odgovornost za pisanje domaćih zadaća uglavnom kao posao roditelja $(\mathrm{Mdn}=5)$, roditelji urbanih sredina u nešto manjoj mjeri odgovornost za pisanje domaćih zadaća pripisuju sebi $(p<0,01)$. Za ostale varijable roditelji iz obje grupe smatraju da su podjednako posao škole i roditelja $(M d n=3)$ iako roditelji urbanih sredina češće vide odgoj i saznanje o tome što je najbolje za njihovo dijete, te zadatak da interveniraju ako u školi nešto nije u redu, kao svoj posao $(p<0,01)$. Roditelji ruralnih sredina skloniji su više procjenjivati svoju odgovornost za to da je dijete sretno u školi, za njegov uspjeh u školi $(\mathrm{p}<0,05)$, te za motiviranje djeteta za učenje $(\mathrm{p}<0,05)$. 
Tablica 1.

Mjere centralnih tendencija i standardne devijacije za varijable iz upitnika "Tradicionalni nasuprot partnerskog odnosa" i urbano/ruralno razlikovanje

\begin{tabular}{|c|c|c|c|c|c|}
\hline Varijable & & Ukupno & Urbano & Ruralno & Značajnost \\
\hline \multicolumn{6}{|l|}{$\begin{array}{l}\text { (od } 1 \text { - u potpunosti je posao } \\
\text { škole do } 5-\text { u potpunosti je } \\
\text { posao roditelja) }\end{array}$} \\
\hline \multirow{5}{*}{$\begin{array}{l}\text { 1. Učiniti sve da nastava bude } \\
\text { dobra }\end{array}$} & M & 1,64 & 1,59 & 1,71 & \\
\hline & $\mathrm{Sd}$ & 0,843 & 0,809 & 0,877 & \\
\hline & Mdn & 1,00 & 1,00 & 1,00 & \\
\hline & $\mathrm{D}$ & 1 & 1 & 1 & \\
\hline & M-W*Rang M & & 508,89 & 544,48 & 0,033 \\
\hline \multirow{5}{*}{$\begin{array}{l}\text { 2. Učiniti sve da postoji dobar } \\
\text { izvannastavni program (kao } \\
\text { razne školske sekcije) }\end{array}$} & M & 1,80 & 1,76 & 1,85 & \\
\hline & $S d$ & 0,898 & 0,881 & 0,914 & \\
\hline & Mdn & 2,00 & 1,00 & 2,00 & \\
\hline & $\mathrm{D}$ & 1 & 1 & 1 & \\
\hline & M-W*Rang M & & 510,75 & 539,12 & 0,101 \\
\hline \multirow{5}{*}{$\begin{array}{l}\text { 3. Učiniti sve da je dijete sigurno } \\
\text { u školi }\end{array}$} & M & 1,82 & 1,81 & 1,83 & \\
\hline & $S d$ & 0,921 & 0,914 & 0,930 & \\
\hline & Mdn & 1,00 & 1,00 & 1,00 & \\
\hline & $\mathrm{D}$ & 1 & 1 & 1 & \\
\hline & M-W*Rang M & & 523,14 & 527,12 & 0,816 \\
\hline \multirow{5}{*}{$\begin{array}{l}\text { 4. Učiniti sve da dijete bude } \\
\text { sretno u školi }\end{array}$} & M & 2,78 & 2,73 & 2,85 & \\
\hline & $\mathrm{Sd}$ & 0,738 & 0,734 & 0,738 & \\
\hline & Mdn & 3,00 & 3,00 & 3,00 & \\
\hline & $\mathrm{D}$ & 3 & 3 & 3 & \\
\hline & M-W*Rang M & & 510,40 & 543,86 & 0,016 \\
\hline \multirow{5}{*}{$\begin{array}{l}\text { 5. Učiniti sve da dijete ima } \\
\text { uspjeha u školi }\end{array}$} & M & 3,04 & 2,99 & 3,09 & \\
\hline & $\mathrm{Sd}$ & 0,567 & 0,560 & 0,572 & \\
\hline & Mdn & 3,00 & 3,00 & 3,00 & \\
\hline & $\mathrm{D}$ & 3 & 3 & 3 & \\
\hline & M-W*Rang M & & 509,10 & 540,02 & 0,012 \\
\hline \multirow{5}{*}{$\begin{array}{l}\text { 6. Intervenirati ako nešto nije u } \\
\text { redu u školi }\end{array}$} & M & 3,13 & 3,20 & 3,04 & \\
\hline & $\mathrm{Sd}$ & 1,013 & 1,034 & 0,983 & \\
\hline & Mdn & 3,00 & 3,00 & 3,00 & \\
\hline & $\mathrm{D}$ & 3 & 3 & 3 & \\
\hline & M-W*Rang M & & 547,23 & 498,52 & 0,003 \\
\hline
\end{tabular}




\begin{tabular}{|c|c|c|c|c|c|}
\hline Varijable & & Ukupno & Urbano & Ruralno & Značajnost \\
\hline \multicolumn{6}{|l|}{$\begin{array}{l}\text { (od } 1 \text { - u potpunosti je posao } \\
\text { škole do } 5 \text { - u potpunosti je } \\
\text { posao roditelja) }\end{array}$} \\
\hline \multirow[t]{5}{*}{ 7. Motivirati dijete da uči } & M & 3,52 & 3,44 & 3,62 & \\
\hline & $\mathrm{Sd}$ & 0,885 & 0,840 & 0,925 & \\
\hline & Mdn & 3,00 & 3,00 & 3,00 & \\
\hline & $\mathrm{D}$ & 3 & 3 & 3 & \\
\hline & M-W*Rang M & & 500,19 & 552,29 & 0,002 \\
\hline \multirow[t]{5}{*}{ 8. Znati što je najbolje za dijete } & M & 3,62 & 3,72 & 3,51 & \\
\hline & $S d$ & 0,899 & 0,932 & 0,848 & \\
\hline & Mdn & 3,00 & 3,00 & 3,00 & \\
\hline & $\mathrm{D}$ & 3 & 3 & 3 & \\
\hline & M-W*Rang M & & 551,26 & 491,75 & 0,000 \\
\hline \multirow{5}{*}{$\begin{array}{l}\text { 9. Odgojiti dijete da postane } \\
\text { dobar čovjek }\end{array}$} & M & 3,64 & 3,70 & 3,56 & \\
\hline & $\mathrm{Sd}$ & 0,809 & 0,822 & 0,789 & \\
\hline & Mdn & 3,00 & 3,00 & 3,00 & \\
\hline & $\mathrm{D}$ & 3 & 3 & 3 & \\
\hline & M-W*Rang M & & 548,42 & 499,31 & 0,004 \\
\hline \multirow{5}{*}{$\begin{array}{l}\text { 10. Učiniti sve da dijete napravi } \\
\text { domaću zadaću }\end{array}$} & M & 4,11 & 4,01 & 4,21 & \\
\hline & $\mathrm{Sd}$ & 0,870 & 0,872 & 0,857 & \\
\hline & Mdn & 4,00 & 4,00 & 4,00 & \\
\hline & $\mathrm{D}$ & 5 & 5 & 5 & \\
\hline & M-W*Rang M & & 492,55 & 559,75 & 0,000 \\
\hline
\end{tabular}

M-aritmetička sredina, Sd - standardna devijacija, Mdn = medijan, D - mod; M-W* Rang M - Mann-Whitney U test - Rang aritmetičkih sredina

\section{Urbano/ruralno razlikovanje u procjenama otvorenosti škole za suradnju, potencijalnih prepreka suradnji roditelja i škole te roditeljskog zadovoljstva suradnjom}

\section{Otvorenost škole}

Iz rezultata prikazanih u Tablici 2 zamjetno je da roditelji u Hrvatskoj otvorenost škole, koja se procjenjuje kroz komunikacijsku otvorenost i međusobno uvažavanje sudionika u komunikaciji roditelj-škola, općenito procjenjuju vrlo visokom. Oni su uglavnom u potpunosti suglasni s tvrdnjama da ih nastavnici tretiraju s poštovanjem kao i vjerovanjem da bi u slučaju nastalih problema naišli na razumijevanje i od strane nastavnika i od strane drugih roditelja $(M d n=4)$. Jedina tvrdnja s kojom 
Tablica 2.

Mjere centralnih tendencija i standardne devijacije za varijable iz upitnika "Procjena otvorenosti škole" i urbano/ruralno razlikovanje

\begin{tabular}{|c|c|c|c|c|c|}
\hline Varijable & & Ukupno & Urbano & Ruralno & Značajnost \\
\hline \multirow{5}{*}{$\begin{array}{l}\text { 1. Razrednik/učitelj me/nas tretira } \\
\text { s poštovanjem. }\end{array}$} & M & 3,76 & 3,71 & 3,82 & \\
\hline & Sd & 0,563 & 0,608 & 0,502 & \\
\hline & Mdn & 4,00 & 4,00 & 4,00 & \\
\hline & D & 4 & 4 & 4 & \\
\hline & M-W*Rang M & & 505,42 & 546,31 & 0,001 \\
\hline \multirow{5}{*}{$\begin{array}{l}\text { 2. Ja/mi možemo lako razgovarati } \\
\text { s razrednikom /učiteljem o } \\
\text { svom djetetu. }\end{array}$} & M & 3,79 & 3,76 & 3,82 & \\
\hline & Sd & 0,532 & 0,561 & 0,496 & \\
\hline & Mdn & 4,00 & 4,00 & 4,00 & \\
\hline & D & 4 & 4 & 4 & \\
\hline & M-W*Rang M & & 511,11 & 538,66 & 0,023 \\
\hline \multirow{5}{*}{$\begin{array}{l}\text { 3. Barem jedan član obitelji često } \\
\text { ode u školu (ovo se ne odnosi } \\
\text { na uzimanje djeteta poslije } \\
\text { škole). }\end{array}$} & M & 3,63 & 3,57 & 3,70 & \\
\hline & $\mathrm{Sd}$ & 0,691 & 0,766 & 0,588 & \\
\hline & Mdn & 4,00 & 4,00 & 4,00 & \\
\hline & D & 4 & 4 & 4 & \\
\hline & M-W*Rang M & & 508,44 & 541,82 & 0,021 \\
\hline \multirow{5}{*}{$\begin{array}{l}\text { 4. Kada bih ja/mi rekli nešto } \\
\text { nastavniku/nastavnicima svog } \\
\text { djeteta, oni bi razumjeli. }\end{array}$} & M & 3,58 & 3,57 & 3,58 & \\
\hline & $\mathrm{Sd}$ & 0,678 & 0,682 & 0,674 & \\
\hline & Mdn & 4,00 & 4,00 & 4,00 & \\
\hline & $\mathrm{D}$ & 4 & 4 & 4 & \\
\hline & M-W*Rang M & & 512,98 & 513,02 & 0,998 \\
\hline \multirow{5}{*}{$\begin{array}{l}\text { 5. Ja/mi nikada ne bismo } \\
\text { razgovarali s ravnateljem /icom } \\
\text { škole jer je vrlo zauzeta. }\end{array}$} & M & 1,55 & 1,57 & 1,52 & \\
\hline & $\mathrm{Sd}$ & 0,992 & 1,009 & 0,975 & \\
\hline & Mdn & 1,00 & 1,00 & 1,00 & \\
\hline & D & 1 & 1 & 1 & \\
\hline & M-W*Rang M & & 490,43 & 483,41 & 0,620 \\
\hline \multirow{5}{*}{$\begin{array}{l}\text { 6. Roditelji u razredu našeg } \\
\text { djeteta bi saslušali ako bih ja/ } \\
\text { mi željeli razgovarati s njima o } \\
\text { nekom problemu. }\end{array}$} & M & 3,45 & 3,45 & 3,46 & \\
\hline & $\mathrm{Sd}$ & 0,795 & 0,770 & 0,823 & \\
\hline & Mdn & 4,00 & 4,00 & 4,00 & \\
\hline & D & 4 & 4 & 4 & \\
\hline & M-W*Rang M & & 498,20 & 514,53 & 0,305 \\
\hline
\end{tabular}

$\mathrm{M}$ - aritmetička sredina, $\mathrm{Sd}-$ standardna devijacija, $\mathrm{Mdn}=$ medijan, $\mathrm{D}$ - mod; M-W* Rang M - Mann-Whitney U test - Rang aritmetičkih sredina 
se roditelji u potpunosti ne slažu (Mdn=1) jest tvrdnja da nikada ne bi razgovarali s ravnateljem škole radi njegove zauzetosti što znači da roditelji i ravnatelja procjenjuju kao osobu koja je dostupna ukoliko prilike to zahtijevaju. Zanimljiva je međutim činjenica da od ukupnog broja ispitanika njih $8,12 \%$ kod ove tvrdnje nije dalo svoju procjenu slaganja ili neslaganja već su se odlučili za "ne mogu procijeniti". Razlike roditelja urbanih i ruralnih sredina u ovoj su procjeni tvrdnje statistički značajne pri čemu se za nemogućnost procjene u populaciji roditelja urbanih područja izjasnilo 12,85\% roditelja (72 roditelja), u odnosu na 3,16\% roditelja (15 roditelja) ruralnih područja (hi-kvadrat $=24,675 ; \mathrm{df}=1, \mathrm{p}<0,01$ ). Za ostale je tvrdnje postotak roditelja koji nisu mogli izraziti svoju procjenu zanemarivo nizak stoga se nismo posebno osvrtali na interpretaciju takvih nalaza.

Urbano/ruralna distinkcija također je vidljiva iz procjena prve tri tvrdnje prikazane u Tablici 2. Naime, iako roditelji i urbanih i ruralnih područja općenito smatraju da ih učitelji poštuju, roditelji iz ruralnih područja u nešto većoj mjeri izjavljuju da ih razrednik tretira $s$ poštovanjem $(\mathrm{p}<0,01)$, kao i da mogu lako razgovarati $s$ učiteljima o svom djetetu $(\mathrm{p}<0,05)$. Vidljivo je također da iako roditelji iz obje populacije često odlaze u školu ( $M d n=4)$ roditelji iz ruralnih sredina, uspoređujući rangove aritmetičkih sredina u Mann-Whitney U testu, daju nešto više procjene od roditelja urbanih sredina $(\mathrm{p}<0,05)$. Za ostale tvrdnje u otvorenosti škole nisu pronađene statistički značajne razlike između roditelja urbanih i ruralnih područja.

\section{Prepreke suradnji roditelja $i$ škole}

Faktorskom analizom čestica koje se odnose na potencijalne prepreke suradnji roditelja i škole ekstrahirana su dva latentna faktora: faktor roditelja i faktor škole. Više procjene označavaju veće prepreke za suradnju međutim iz aritmetičkih sredina kompozitnih rezultata čestica prvog i drugog faktora vidljivo je da se roditelji uglavnom ne slažu s navedenim tvrdnjama. Takvi nalazi impliciraju da roditelji bazično ne vide niti roditelje niti školu kao prepreku u komunikaciji roditelji-škola, iako sebe, svoje stavove i ponašanja, vide kao nešto veću prepreku za suradnju (Tablica 3). Za faktor škole distinkcija urbano/ruralno ne postoji međutim za faktor roditelja dobivena je razlika u smjeru da roditelji urbanih sredina, u smislu postavljenih tvrdnji, vide faktor roditelja kao veću prepreku od roditelja ruralnih sredina $(\mathrm{p}<0,05)$. 
Tablica 3.

Mjere centralnih tendencija i standardne devijacije za kompozitne varijable faktor škole i faktor roditelja kao prepreka uključenosti roditelja u školovanje djeteta, s prikazom urbano/ruralnog razlikovanja

\begin{tabular}{|c|c|c|c|c|c|}
\hline Prepreke u suradnji & & Ukupno & Urbano & Ruralno & Značajnost \\
\hline \multirow{5}{*}{$\begin{array}{l}\text { 1. Faktor škole - Škola kao } \\
\text { prepreka uključenosti roditelja } \\
\text { u školovanje djeteta }\end{array}$} & M & 1,48 & 1,49 & 1,45 & \\
\hline & $\mathrm{Sd}$ & 0,559 & 0,552 & 0,566 & \\
\hline & Mdn & 1,20 & 1,40 & 1,20 & \\
\hline & $\mathrm{D}$ & 1 & 1 & 1 & \\
\hline & M-W*Rang M & & 537,58 & 507,40 & 0,095 \\
\hline \multirow{5}{*}{$\begin{array}{l}\text { 2. Faktor roditelja - Roditelji kao } \\
\text { prepreka vlastite uključenosti u } \\
\text { školovanje djeteta }\end{array}$} & M & 1,95 & 2,00 & 1,90 & \\
\hline & $\mathrm{Sd}$ & 0,782 & 0,793 & 0,766 & \\
\hline & Mdn & 2,00 & 2,00 & 2,00 & \\
\hline & $\mathrm{D}$ & 1 & 1 & 1 & \\
\hline & M-W*Rang M & & 538,64 & 500,85 & 0,040 \\
\hline
\end{tabular}

$M$ - aritmetička sredina, Sd - standardna devijacija, Mdn = medijan, D - mod;

M-W* Rang M - Mann-Whitney U test - Rang aritmetičkih sredina

\section{Zadovoljstvo komunikacijom i mogućnošću utjecaja}

Iz Tablice 4, kao i iz grafičkih prikaza, vidljivo je da su roditelji općenito prilično zadovoljni komunikacijom sa školom i mogućnošću utjecaja na školu, međutim najveće zadovoljstvo pokazuju kvalitetom i kvantitetom informacija koje dobivaju iz škole $(M d n=4)$, a najmanje načinima na koje mogu utjecati na školu $(M d n=3)$. Urbano-ruralno razlikovanje nije prisutno jedino u zadovoljstvu kvalitetom i kvantitetom informacija koje roditelji dobivaju od škole, dok su roditelji ruralnih sredina uglavnom nešto zadovoljniji različitim načinima na koje se mogu uključiti u rad škole $(p<0,05)$, načinima na koje mogu utjecati na obrazovanje svog djeteta $(\mathrm{p}<0,01)$ i načinima na koje mogu utjecati na školu općenito $(\mathrm{p}<0,01)$. 
Tablica 4.

Mjere centralnih tendencija i standardne devijacije za varijable iz područja zadovoljstva ostvarenom komunikacijom sa školom i mogućnosti utjecaja na obrazovanje s prikazom urbano/ruralnog razlikovanja

\begin{tabular}{|c|c|c|c|c|c|}
\hline Varijable & & Ukupno & Urbano & Ruralno & Značajnost \\
\hline \multicolumn{6}{|l|}{ Komunikacija sa školom } \\
\hline \multirow{5}{*}{$\begin{array}{l}\text { 1. Ja/mi smo zadovoljni kvalitetom } \\
\text { i kvantitetom informacija koje } \\
\text { dobivamo od škole. }\end{array}$} & M & 3,29 & 3,27 & 3,32 & \\
\hline & Sd & 0,889 & 0,888 & 0,891 & \\
\hline & Mdn & 4,00 & 4,00 & 4,00 & \\
\hline & D & 4 & 4 & 4 & \\
\hline & $M-W^{*}$ Rang $M$ & & 514,59 & 531,45 & 0,321 \\
\hline \multirow{5}{*}{$\begin{array}{l}\text { 2. Ja/mi smo zadovoljni različitim } \\
\text { načinima na koje se možemo } \\
\text { uključiti u rad škole. }\end{array}$} & M & 2,95 & 2,87 & 3,04 & \\
\hline & Sd & 1,005 & 1,024 & 0,977 & \\
\hline & Mdn & 3,00 & 3,00 & 3,00 & \\
\hline & $\mathrm{D}$ & 4 & 4 & 4 & \\
\hline & M-W*Rang M & & 489,00 & 533,30 & 0,012 \\
\hline \multicolumn{6}{|l|}{ Utjecaj } \\
\hline \multirow{5}{*}{$\begin{array}{l}\text { 3. Ja sam/mi smo zadovoljni } \\
\text { načinima na koje možemo } \\
\text { utjecati na obrazovanje svog } \\
\text { djeteta. }\end{array}$} & M & 2,85 & 2,70 & 3,02 & \\
\hline & Sd & 1,038 & 1,064 & 0,984 & \\
\hline & Mdn & 3,00 & 3,00 & 3,00 & \\
\hline & $\mathrm{D}$ & 4 & 4 & 4 & \\
\hline & M-W*Rang M & & 475,29 & 560,33 & 0,000 \\
\hline \multirow{5}{*}{$\begin{array}{l}\text { 4. Ja sam/mi smo zadovoljni } \\
\text { načinima na koje možemo } \\
\text { utjecati na školu općenito. }\end{array}$} & M & 2,62 & 2,49 & 2,76 & \\
\hline & $\mathrm{Sd}$ & 1,047 & 1,067 & 1,006 & \\
\hline & Mdn & 3,00 & 3,00 & 3,00 & \\
\hline & D & 3 & 3 & 3 & \\
\hline & M-W*Rang M & & 479,32 & 551,62 & 0,000 \\
\hline
\end{tabular}

$\mathrm{M}$ - aritmetička sredina, Sd - standardna devijacija, $\mathrm{Mdn}=$ medijan, $\mathrm{D}$ - mod; M-W* Rang M - Mann-Whitney U test - Rang aritmetičkih sredina 


\section{Graf 1}

Usporedba roditelja urbanih i ruralnih područja: zadovoljstvo kvalitetom i kvantitetom informacija

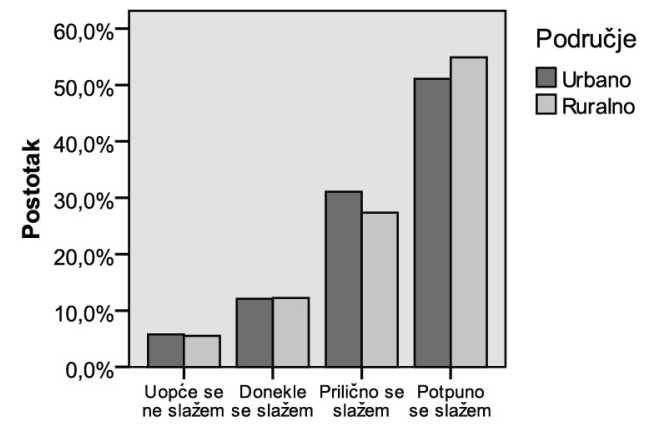

Graf 2.

Usporedba roditelja urbanih i ruralnih područja: zadovoljstvo načinima participacije u školi

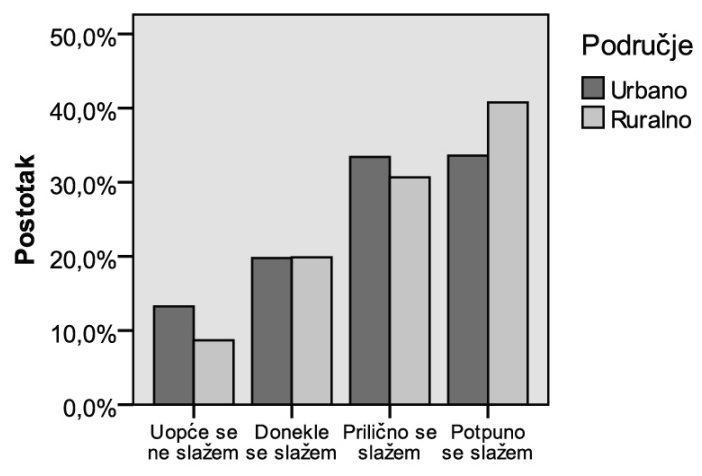

\section{RASPRAVA}

Rezultati istraživanja stavova roditelja o tome što je posao roditelja, a što posao škole u procesu odgoja i obrazovanja djece upućuju na zaključak da roditelji u Hrvatskoj sebe ne doživljavaju kao značajnog čimbenika koji bi mogao ili trebao pridonijeti poboljšanju same kvalitete obrazovanja. Naime, izražavanjem stavova da su kvaliteta nastave, odabir izvannastavnih aktivnosti i sigurnost djeteta u školi uglavnom ili gotovo u potpunosti posao škole, oni prilično jasno izražavaju tradicionalno usmjerenje kada je u pitanju obrazovanje (Tablica 1). Takav stav može biti prepreka roditeljskom angažmanu u planiranju i organiziranju nastave, izvannastavnih aktivnosti i strategija za povećanje sigurnosti učenika u školi, a što je u velikom broju zemalja Europe uobičajena praksa koja olakšava posao nastavnicima i zaposlenima i omogućuje im da se više posvete svojim profesionalnim obavezama. Primjera radi, Sliwka i Istance (2006.) u svojim nalazima meta-analize roditeljske uključenosti u školovanje djece navode da se prema istraživanju CBOS (2000.) čak 65\% roditelja iz Poljske izjasnilo kako uključenost u izradu školskog pedagoškog programa vide kao prioritet. Roditelji iz Finske, Austrije i Danske pu- 
tem školskih tijela također mogu utjecati na izradu kurikuluma, pri čemu su se danski roditelji izjasnili da bi u okviru izrade kurikuluma željeli utjecati samo na neka posebna pitanja poput efikasnog poučavanja, odabira stranih jezika ili informatičke tehnologije. Međutim, u širem istraživanju roditeljske participacije u Hrvatskoj, provedenog od strane Open Society Institute 2009. godine, a u čiji okvir spadaju i rezultati ovog rada, analiza roditeljskih odgovora pokazuje da velika većina roditelja izražava želju za sudjelovanjem u nastavi i uključenjem u donošenje odluka, te smatra da bi ih škola trebala tražiti mišljenje o pitanjima koja se tiču obrazovanja njihove djece (Miljević-Riđički i Pahić, 2010.; Pahić, Miljević-Riđički i Vizek Vidović, 2010.). Problem je međutim u tome, ako uzmemo u obzir i zaključak istraživanja Hornby i Lafaele (2011.) da roditeljsko viđenje školskih poziva na uključivanje u rad škole predstavlja ključ ostvarenja dobre suradnje, što roditelje u Hrvatskoj škole rijetko pozivaju na suradnju. Naime, čak 82,9\% roditelja u Hrvatskoj škole niti jednom nisu tražile mišljenje o obrazovnim temama koje bi uključivale sadržaj lekcija, odabir udžbenika, procjene nastavnika ili opterećenosti učenika, 88,2\% roditelja nikada nije primilo poziv za sudjelovanje (pomoć) u nastavi, $68,4 \%$ roditelja škola nikada nije tražila mišljenje o slobodnim aktivnostima, a 68,9\% njih škola nije nikada tražila mišljenje o zdravlju i sigurnosti djece (Miljević-Riđički i Pahić, 2010.). Iz ovih nalaza čini se da su roditelji prilično spremni za proširenje suradnje sa školom, međutim inicijativa svakako mora doći od strane škole. Pritom je također potrebno obratiti pažnju na nalaze Hornby i Witte (2010.b) koji ukazuju da je uključivanje roditelja puno uspješnije kad ga organizira sama škola, nego kad se škole rukovode nekim opće propisanim programima suradnje. Iako roditelji u ovom istraživanju procjenjuju nastavu i izvannastavne aktivnosti kao isključivo posao škole (Tablica 1), vidljivo je da je i njima jasno da je, kako kaže Jurčić (2005.) tradicionalna uloga roditelja i škole, u kojoj je odgoj isključivo posao roditelja a obrazovanje učitelja već odavno zastarjela. Roditelji provode sve manje vremena kod kuće s djecom tako da su jedan dio odgojne uloge svakako morali prepustiti školi ili je bar podijeliti s njom. Pozitivno je da su roditelji postali svjesni zajedničke, partnerske uloge koju roditelji i škola imaju u odgoju djeteta i stvaranju djetetovog pozitivnog odnosa prema školi jer je partnerski odnos zapravo proces u kojem uključene strane podupiru jedna drugu u cilju poboljšanja učenja, motivacije i razvoja učenika (Epstein, 1995.). Iako su roditeljske procjene iz ugla urbano/ruralnog razlikovanja prilično ujednačene, vidljivo je da postoje male iako statistički značajne razlike u pogledu većine pitanja o tome što je posao škole a što roditelja u procesu školovanja djeteta. Zanimljivo je da roditelji iz urbanih sredina imaju tendenciju procjenjivati odgojne zadaće u većoj mjeri kao posao roditelja, a obrazovne više kao posao škole nego što to procjenjuju roditelji iz ruralnih sredina (Tablica 1). Ovakav nalaz moguće odražava i naglašava upravo situacijski kontekst na način da škole u urbanim sredinama vjerojatno češće traže suradnju i pomoć roditelja oko discipliniranja i ponašanja djece u školi te upozoravaju roditelje na važnost odgoja unutar obitelji. S druge strane, škole u ruralnim sredinama često imaju mnogo manji broj učenika od gradskih škola i disciplinskih problema je manje, a roditelje se češće poziva na suradnju i uključenje upravo u obrazovnim aspektima kako bi, s obzirom na prilično lošu obrazovnu strukturu stanovništva naših ruralnih područja, motivirali djecu na učenje i poticali kod njih obrazovne 
aspiracije. Nadalje, odnos koji škola ima prema roditeljima, dostupnost učitelja, otvorenost u komunikaciji, stručnost školskog osoblja kao i spremnost na suradnju ključni su preduvjeti za postizanje dobre suradnje s roditeljima koja s druge strane predstavlja preduvjet za ostvarivanje zajedničkih odgojno-obrazovnih ciljeva škole i roditelja (Borg i Mayo, 2001.; Feuerstein, 2000.). Iz nalaza provedenog istraživanja čini se da je, prema procjenama roditelja, velik broj pretpostavki uspješne suradnje roditelja i škole u Hrvatskoj zadovoljen. Naime, kod većine obitelji barem jedan član roditelja često odlazi u školu, a u školi najčešće nailaze na poštovanje i razumijevanje od strane učitelja, ravnatelja i drugih roditelja (Tablica 2). Urbano/ ruralna distinkcija koju nalazimo kod nekih procjena otvorenosti škole sukladna je našoj hipotezi o postojanju razlike u roditeljskoj uključenosti u školovanje djeteta kao i dosadašnjim istraživačkim nalazima (npr. Hornby i Witte, 2010.a; McBride i sur., 2002.; Sliwka i Instance, 2006.) koji ukazuju na lakše ostvarivanje suradnje, bolju komunikaciju sa školom i veću uključenost roditelja u rad škole u ruralnim sredinama. Prema Bauch (2001.:208.) "sposobnost prilagodbe na partnerski model školovanja prirodniji je za seoske nego za gradske sredine". Kao što je ranije navedeno, roditelji ruralnih sredina bolje se međusobno poznaju, škola i zajednica više su povezane, a bolje poznavanje roditelja i učitelja u malom mjestu stanovanja vodi ka većem razumijevanju i kvalitetnijoj suradnji. U prilog tome govori i podatak iz našeg istraživanja o procjeni dostupnosti ravnatelja škole za razgovor. Naime, postotak roditelja urbanih područja koji nisu mogli procijeniti dostupnost ravnatelja škole bio je značajno veći u odnosu na roditelje ruralnih područja.

Spremnost i osposobljenost za komunikaciju roditelj-škola roditelji urbanih i ruralnih područja Hrvatske uglavnom procjenjuju visokom iako roditeljski nedostatak vremena, interesa i komunikacijskih vještina doživljavaju, u odnosu na školu, kao veću prepreku suradnji (Tablica 3). Ovakav nalaz ukazuje na roditeljsku samokritičnost i spremnost na prihvaćanje svog dijela odgovornosti u međusobnom odnosu sa školom, međutim neupitno je da bi inicijative za suradnju uglavnom trebale dolaziti od strane škole što roditelji i očekuju (Miljević-Riđički i Pahić, 2010; Pahić i sur., 2010.). Nalazi provedenog istraživanja ukazuju da roditelji ruralnih područja statistički značajno manje u odnosu na roditelje urbanih područja navode problem nedostatka vremena kao prepreku sudjelovanja u životu škole svog djeteta. Međutim, dobivene urbano-ruralne razlike u procjenama su male što je vrlo vjerojatno posljedica sve većeg utjecaja urbanizacije i sve manje jasnih granica između ruralnog i urbanog. Većina se takozvanih ruralnih područja po nekim obilježjima života sve manje razlikuje od života u gradovima - sve je više stanovnika sela koji rade u gradovima i svakodnevno izbivaju iz mjesta stanovanja što i kod njih smanjuje vrijeme i prostor za međusobnu komunikaciju i komunikaciju sa školom. Iz tog razloga moguće je da će specifičnosti odnosa škole i roditelja u ruralnim zajednicama kakve danas podrazumijevamo tijekom vremena sve više blijedjeti.

Većina rezultata ovog istraživanja, uključujući i rezultate globalnog, roditeljske procjene zadovoljstva komunikacijom sa školom i utjecaja na školu, ukazuju na općenito pozitivan stav roditelja prema školi u Hrvatskoj. Naime, može se reći da je većina roditelja u potpunosti zadovoljna kvalitetom i količinom informacija koje 
dobivaju od škole, kao i da su roditelji uglavnom zadovoljni različitim načinima na koje se mogu uključiti u rad škole. Dok se kod zadovoljstva kvalitetom i kvantitetom informacija ne nalaze urbano/ruralne razlike, rezultati pokazuju da su roditelji ruralnih područja zadovoljniji različitim načinima participacije u životu škole. Ovakav nalaz potvrđuje nalaze ranije provedenih fokus grupa s roditeljima urbanih i ruralnih područja koji se navode u uvodnom dijelu rada - dok su roditelji ruralnih područja zadovoljni svojim sudjelovanjem u prigodnim zajedničkim radionicama s djecom i prilikama da na roditeljskim sastancima u manjim grupama diskutiraju određene probleme, roditelji urbanih područja izjavljuju da su previše zauzeti poslom i drugim obavezama da bi se više uključili u život škole. O urbano/ruralnim razlikama u uključenosti u život škole govori i istraživanje provedeno u Poljskoj (Sliwka i Instance, 2006.) čiji nalazi ukazuju da 20\% roditelja ruralnih u odnosu na 15\% roditelja urbanih sredina ima neku funkciju u školi, školskom vijeću ili vijeću roditelja. Navedeno govori u prilog činjenici da neka obilježja ruralnih sredina doprinose lakšoj suradnji sa školom što u konačnici rezultira većim zadovoljstvom načinima participacije u školi (Graf 2). Iako uglavnom zadovoljni načinima na koje mogu utjecati na školu i obrazovanje svog djeteta, roditelji ipak iskazuju nešto manje zadovoljstvo u odnosu na komunikaciju koju ostvaruju sa školom. Prethodni nalazi ovog istraživanja (Miljević-Riđički i Pahić, 2010.; Pahić i sur., 2010.) govore da škole gotovo nikada ne uključuju roditelje u organizaciju i sudjelovanje u nastavi i izvannastavnim aktivnostima kao niti u donošenje odluka koje se tiču škole i obrazovanja, što u kontekstu roditeljskog zadovoljstva vrlo vjerojatno rezultira smanjenim zadovoljstvom mogućnošću utjecaja na školu i obrazovanje. Nalazi meta-analize Sliwka i Instance (2006.) govore da se slična situacija može naći i u drugim europskim zemljama poput Poljske, Mađarske i Češke u kojima je područje roditeljskog utjecaja prilično limitirano. U tim se zemljama roditelje uglavnom poziva na sudjelovanje u vezi nekih svakodnevnih pitanja i praktičnih aktivnosti ali ne i na sudjelovanje u fundamentalnim pitanjima vezanima uz obrazovanje i školu. Iako postoji zakonska regulativa prema kojoj bi roditelji preko Vijeća roditelja škole u Hrvatskoj trebali biti uključeni u donošenje školskog kurikuluma, te izradu godišnjeg plana i programa (Zakon o odgoju i obrazovanju u osnovnoj i srednjoj školi, 2008., Članak 137/4.) nalazi Pahić i sur. (2010.) govore da se roditelje gotovo nikada ne pita za mišljenje po tim pitanjima, niti ih se traži mišljenje o upravljanju školskim financijama, sveukupnom upravljanju školom, izvannastavnim aktivnostima i slično. Tendencija ka decentralizaciji školske uprave na lokalnu razinu povezana je upravo i s povećanim značajem uloge roditelja u razvoju škole. Međutim, Daniel (2011.) navodi da u takvoj proširenoj suradnji škole i roditelja može doći do otpora od strane ravnatelja i učitelja koji se mogu osjetiti ugroženima zbog prevelike prisutnosti i uključenosti roditelja u školski sustav. Durbin, Miljević i Pop (2009.) navode da je većina ravnatelja u Europi uglavnom protiv toga da roditelji budu uključeni u izbor udžbenika iz čega je vidljivo da škola želi zadržati određenu razinu potrebne autonomije koja joj nikako ne bi smjela biti uskraćena. Iako nalazi istraživanja Pahić i sur. (2010.) govore da bi roditelji u Hrvatskoj željeli biti uključeni u odlučivanje u svim segmentima rada škole, istraživanja u Danskoj i Finskoj, zemljama gdje roditelji već dulje vrijeme imaju gotovo esencijalnu ulogu u vođenju škole i gdje postoji stalni razvoj kooperacije škole i obitelji, pokazuju da 
se većina roditelja uglavnom ne želi miješati u pitanja načina i sadržaja poučavanja (Sliwka i Instance, 2006.) što učiteljima u nihovom radu ostavlja dovoljno prostora za autonomiju. Međutim, kao što je ranije navedeno, inicijativa za sudjelovanje roditelja u životu škole svakako mora doći od strane škole, a needuciranost učitelja o tome kako facilitirati kooperaciju s roditeljima može biti prepreka tom procesu (Tichenor, 2010.). Premda je Finska zemlja s dugom tradicijom suradništva škole i obitelji i tamo je suradnja s roditeljima jedna od deset najslabije zastupljenih domena obrazovanja učitelja (Apajalahti i Merimaa, 1996.; Niemi i Tirr, 1997., prema Sliwka i Istance, 2006.). Daniel (2011.) sugerira da bi tom problemu trebalo posvetiti posebnu pažnju ukoliko se uzme u obzir da upravo učitelji koji su otvoreni i puštaju roditelje da utječu na njihov rad imaju najbolje rezultate i roditelji ih ocjenjuju boljima. Urbano/ ruralna distinkcija roditeljskog zadovoljstva utjecajem na školu i obrazovanje, u nalazima provedenog istraživanja, pokazuje da su roditelji ruralnih područja zadovoljniji svojim utjecajem od roditelja urbanih područja, a iz dosad navedenih nalaza mogli bismo zaključiti da razlog njihovog većeg zadovoljstva između ostalog svakako predstavlja i bolja komunikacija i suradnja koju ostvaruju sa školom. Međutim, prostor za poboljšanje komunikacije i suradnje škole i roditelja postoji u školama obiju sredina. U prvom redu, sukladno roditeljskom izjašnjavanju o postojanju potrebe za većim utjecajem na školu i obrazovanje, potrebno je ispitati koliko su roditelji u Hrvatskoj uopće upoznati s mogućnostima svog djelovanja te ih upoznati s načinima i mjerom u kojoj mogu biti uključeni u različite oblike sudjelovanja i formalnih procedura donošenja odluka. Istovremeno je potrebno u okviru programa trajnog stručnog usavršavanja educirati ravnatelje škola i učitelje o različitim mogućnostima suradnje s roditeljima i važnosti partnerskog odnosa škole i roditelja kao važnog čimbenika akademskog postignuća učenika i njihovog zadovoljstva školom.

\section{ZAKLJUČAK}

Nalazi provedenog istraživanja sugeriraju da, iako roditelji u nekim segmentima na svoju ulogu u školovanju djeteta još uvijek gledaju iz aspekta tradicionalnog sustava te smatraju kako bi kvaliteta nastave i sigurnost djece u školi trebala biti isključivo odgovornost škole, odgoj djeteta i njegovo zadovoljstvo školom vide kao zajedničku odgovornost škole i roditelja, što svakako predstavlja put ka razvoju partnerskog odnosa škole i roditelja. Osim toga, većina se roditelja u Hrvatskoj u školi osjeća uvaženo i poštovano i premda roditelji smatraju da ne postoje prepreke suradnji između njih i škole oni uglavnom vide vlastiti nedostatak vremena kao najznačajniju prepreku njihovoj suradnji. Većina je roditelja u potpunosti zadovoljna kvalitetom i kvantitetom informacija koju dobivaju od škole te prilično zadovoljna različitim načinima na koje se mogu uključiti u rad škole i utjecati na obrazovanje svog djeteta kao i na školu općenito.

Urbano/ruralne distinkcije roditeljskih procjena većim dijelom potvrđuju polaznu pretpostavku te ukazuju na veću povezanost roditelja i škole u ruralnim područjima, kao i općenito veće zadovoljstvo komunikacijom i utjecajem na školu kod roditelja ruralnih područja. 


\section{Literatura}

Bauch, P. A. (2001). School-Community Partnership in Rural Schools: Leadership, Renewal and a Sense of Place. Peabody Journal of Education, 76(2):204-221.

Borg, C. i Mayo, P. (2001). From "Adjuncts" to "Subjects": parental involvement in a workingclass community. British Journal of Sociology of Education, 22(2):245-266.

Daniel, G. (2011). Family-school partnerships: towards sustainable pedagogical practice. Asia-Pacific Journal of Teacher Education, 39(2):165-176.

Dauber, S. L. i Epstein, J. L. (1989). Parent attitudes and practices of parent involvement in inner-city elementary and middle schools (Report No. 33). U.S. Department of Education, Office of Educational Research and Improvement. Educational Resources Information Center (ERIC). February 2010.

Durbin, Y., Miljević, G. i Pop, D. (2009). Uključenost roditelja u rad škola u jugoistočnoj Evropi: stavovi direktora. Ljubljana: Pedagogška fakulteta Univerze v Ljubljani.

Epstein, J. (1995). School/family/community partnership: caring for the children we share. Phi Delta Kappan, May: 701-712.

Epstein, J. L.; Sanders, M. G.; Sheldon, S. B.; Simon, B. S. (2009). School, Family and Community Partnership. London: Corwin Press, SAGE.

Feuerstein, A. (2000). School Characteristics and Parental Involvement: Influences on Participation in Children's Schools. The Journal of Educational Research, 94:29-40.

Hornby, G. i Witte, C. (2010a). Parent Involvement in Rural Elementary Schools in New Zealand: A Survey. Journal of Child and Family Studies, 19:771-777.

Hornby, G. i Witte, C. (2010b). Parental involvement in secondary schools in New Zealand: Implication for school psychologists. School Psychology International, 31(5):495-508.

Hornby, G. i Lafaele, R. (2011). Barriers to parental involvement in education: an explanatory model. Educational Review, 63(1):37-52.

Jeynes, W. H. (2005). A Meta-Analysis of the Relation of Parental Involvement to Urban Elementary School Student Academic Achievement. Urban Education, 40(3):237-269.

Jurčić, M. (2005). Zadovoljstvo roditelja osnovnom školom i njibova spremnost za suradnju. (Doktorska disertacija). Zagreb: Filozofski fakultet.

Kainz, K. i Aikens, N. L. (2007). Governing the Family through Education: A Genealogy on the Home/School Relation. Equity \& Excellence in Education, 40:301-310.

McBride, B. A., Bae, J. H. i Wright, M. S. (2002). An Examination of Family-School Partnership Initiatives in Rural Prekindergarten Programs. Early Education and Development, 13(1):107-127.

Miljević-Riđički, R. i Pahić, T. (2010). National Survey of Parents in Croatia, u: Miljević, G. (Ur.). School governance and social inclusion: Involvement of parents - South East Europe Countries Accounts of Parents' Views. Pregledano 01. travnja 2011. (http://www. see-educoop.net/aeiq/outputs/Knjiga\%204\%20LQ.pdf).

Pahić, T., Miljević-Riđički, R. i Vizek Vidović, V. (2010). Uključenost roditelja u život škole: percepcija roditelja opće populacije i predstavnika roditelja u školskim tijelima. Odgojne znanosti, 12, 2(20):329-346.

Republika Hrvatska, Ministarstvo znanosti, obrazovanja i športa (2010). Zakon o odgoju i obrazovanju u osnovnoj i srednjoj školi. Pregledano 06. lipnja 2010. (http://public. mzos.hr/Default.aspx?sec=2194).

Sheridan, S. M. i Kratochwill, T. R. (2007). Conjoint Behavioral Consultation: Promoting Family-School Connections and Interventions. London: Springer.

Sliwka, A. i Istance, D. (2006). Parental and Stakeholder "Voice" in Schools and Systems. European Journal of Education, 41(1):29-43.

Tichenor, M. S. (2010). Preservice teachers' attitudes toward parent involvement: Implications for teacher education. The Teacher Educator, 33(4):248-259. 
Prilog 1.

Kategorizacija škola prema veličini, regijama i urbano/ruralnoj distinkciji

\begin{tabular}{|c|c|c|c|c|}
\hline Škola & $\begin{array}{l}\text { Veličina škole } \\
\text { (broj učenika) }\end{array}$ & Regija & Urbano-ruralno & $\begin{array}{l}\text { Okvirni broj stanovnika u } \\
\text { naselju u kojem se nalazi } \\
\text { škola }\end{array}$ \\
\hline 1 & 75 & $\begin{array}{l}\text { Istra, Rijeka, Sjeverno hrvatsko } \\
\text { primorje, Gorski kotar }\end{array}$ & Ruralno & 1.000 \\
\hline 2 & 150 & $\begin{array}{l}\text { Istra, Rijeka, Sjeverno hrvatsko } \\
\text { primorje, Gorski kotar }\end{array}$ & URBANO & 100.000 \\
\hline 3 & 163 & Lika i Banovina & Ruralno & 3.000 \\
\hline 4 & 170 & Sjeverna Hrvatska & Ruralno & 2.000 \\
\hline 5 & 174 & Slavonija & Ruralno & 2.000 \\
\hline 6 & 194 & Dalmacija & Ruralno & 2.000 \\
\hline 7 & 270 & Zagreb i okolica & Ruralno & 3.000 \\
\hline 8 & 270 & Lika i Banovina & Ruralno & 5.000 \\
\hline 9 & 297 & Sjeverna Hrvatska & Ruralno & 2.000 \\
\hline 10 & 354 & $\begin{array}{l}\text { Istra, Rijeka, Sjeverno hrvatsko } \\
\text { primorje, Gorski kotar }\end{array}$ & URBANO & 100.000 \\
\hline 11 & 354 & Dalmacija & URBANO & 30.000 \\
\hline 12 & 372 & Dalmacija & Ruralno & 4.000 \\
\hline 13 & 376 & Slavonija & Ruralno & 6.000 \\
\hline 14 & 397 & Lika i Banovina & Ruralno & 7.000 \\
\hline 15 & 405 & Zagreb i okolica & URBANO & 800.000 \\
\hline 16 & 405 & $\begin{array}{l}\text { Istra, Rijeka, Sjeverno hrvatsko } \\
\text { primorje, Gorski kotar }\end{array}$ & Ruralno & 2.000 \\
\hline 17 & 407 & Slavonija & URBANO & 5.000 \\
\hline 18 & 412 & Sjeverna Hrvatska & Ruralno & 6.000 \\
\hline 19 & 529 & Sjeverna Hrvatska & URBANO & 8.000 \\
\hline 20 & 550 & Zagreb i okolica & Ruralno & 7.000 \\
\hline 21 & 653 & $\begin{array}{l}\text { Istra, Rijeka, Sjeverno hrvatsko } \\
\text { primorje, Gorski kotar }\end{array}$ & URBANO & 60.000 \\
\hline 22 & 667 & Lika i Banovina & URBANO & 10.000 \\
\hline 23 & 711 & Slavonija & URBANO & 60.000 \\
\hline 24 & 730 & Zagreb i okolica & URBANO & 800.000 \\
\hline 25 & 738 & Slavonija & URBANO & 17.000 \\
\hline 26 & 813 & Dalmacija & URBANO & 8.000 \\
\hline 27 & 902 & Sjeverna Hrvatska & URBANO & 15.000 \\
\hline 28 & 938 & Lika i Banovina & URBANO & 13.000 \\
\hline 29 & 940 & Zagreb i okolica & URBANO & 60.000 \\
\hline 30 & 1126 & Dalmacija & URBANO & 70.000 \\
\hline
\end{tabular}


Original scientific work

Renata Miljević-Riđički

Faculty of Teacher Education, University of Zagreb

Tea Pahić

Faculty of Teacher Education, Čakovec

Vlasta Vizek Vidović

Institute for Social Research in Zagreb,

Center for Educational Research and Development

renata.miljevic@ufzg.hr

\title{
Parents and School Cooperation in Croatia: Similarities and Differences in Urban and Rural Settings
}

\begin{abstract}
The aim of this study was to explore parents' perceptions of their cooperation with the school which their children attend as well as to examine possible differences in their orientations toward cooperation with schools which function in rural or urban settings. The comparisons between those two parent subsamples was carried out regarding their perception of school openness, factors acting as potential barriers to cooperation with school and general satisfaction with the possibility to influence their child education. The theoretical basis of the study was Joyce Epstein model of parental involvement (Epstein at al., 2009) and Sheridan and Kratochwill concept of school-parent partnership (Sheridan and Kratochwill, 2007). The total sample consisted of 1052 parents of children from the second to the eights grade of 30 elementary schools in Croatia, out of which 16 school were from urban and 14 school from rural settings. Regarding the characteristics of the data parametric and non-parametric statistical analyses were performed. The results indicate that in some aspects of parental cooperation with the school parents dominantly keep traditional perspective on child education while the child up-bringing and satisfaction with school perceive as shared responsibility of both school and parents. In accordance with the initial assumptions the results on urban/rural distinctions indicate higher level of cooperation between school and parents in rural settings as well as higher levels of general satisfaction with school and possibility to influence school decision making.
\end{abstract}

Key words: urban/rural schools, parental involvement in education, parental orientation toward cooperation with school. 